\title{
Crossing the Border Between Elitist and Popular Literature: A Comparative Analysis of Goethe's Bride of Corinth and Meyer's Twilight Saga
}

\author{
Sayaka Oki \\ Doshisha University, Japan.
}

How to cite this paper: Sayaka Oki. (2021) Crossing the Border Between Elitist and Popular Literature: A Comparative Analysis of Goethe's Bride of Corinth and Meyer's Twilight Saga. Journal of Humanities, Arts and Social Science, 5(1), 166-178.

DOI: $10.26855 /$ jhass.2021.01.017

Received: April 17, 2021

Accepted: May 12, 2021

Published: June 21, 2021

"Corresponding author: Sayaka Oki, Doshisha University, Japan.

Email: sayaka.oki@hotmail.com

\begin{abstract}
This paper aims to analyze the image of the spiritual vampire in Goethe's Bride of Corinth (1797) and Meyer's Twilight series (2005-2010). Written at the end of the $18^{\text {th }}$ century in the High Classical literary period, Goethe's work does not seem to suit the trivial, cannibalistic subject of the vampire as a literary theme, yet has focused on the high literary motif of "mentality" to construct a spiritual vampire bride who falls in love with a pagan youth. This paper interprets Goethe's ballade as the significant origin of the notion of the love story between a spiritual vampire and a human being. This motif was further developed in Meyer's postmodern literature series, Twilight, through the romance between an idealized vampire, Edward Cullen, and an adolescent girl, Bella Swan. Meyer's Twilight became an international bestseller with cross-generational fandom. From these contexts, this paper examines depictions of absolute love between vampires and human beings in both literary works, along with their symbolic meanings. Accordingly, crucial themes considered include religious differences, gender roles, marginalization (of freaks of nature), and binary tropes. Framed by Leslie Fiedler's literary theory of postmodernism, the paper demonstrates the ways in which the vampire motif of Meyer's saga bridges the gap between high and low/popular culture by reproducing elements of prototypical folklores and fairy tales for modern mass consumption.
\end{abstract}

\section{Keywords}

Vampires, Popular Literature, Postmodernism, Freaks, Cannibalism, Romance

\section{Introduction}

Historically, various types of stories concerning the undead/vampires have largely circulated through oral dissemination, and, to a lesser extent, in the form of protocols or literary papers. The human hope to conquer aging and illness through immortality has underscored the appearance of the undead in literature and the arts. The most famous vampire novel, Dracula, was written by Bram Stoker in 1897. It was frequently adapted to film in the $20^{\text {th }}$ century by such directors as F. W. Murnau (1922), Tod Browning (1931), Carl Theodor Dreyer (1932), and Terence Fisher (1958). Moreover, Dracula has been reinterpreted for various generations and cultures across the globe. The literary motif of vampires can be traced back to European legend. It has since been embraced with enthusiasm by both high and popular culture. A testament to popular appeal, print media with vampires as subjects has become international bestsellers. Simultaneously, the subject has also captured the attention of scholars, providing research and teaching material. 
Johann Wolfgang von Goethe's poem was written in 1797, exactly a century before Stoker's Dracula. The former is based on a ghost story by the ancient Greek writer, Phlegon of Trailles (Trunz, 2000). In the $2^{\text {nd }}$ century A.D., Phlegon collected mysterious anecdotes-particularly those involving the undead, ghosts, "freaks," hermaphrodites, and giants-for his book, Das Buch der Wunder (The Book of Miracles). Centuries later, Goethe reinterpreted Phlegon's ghost story poetically. Notably, the cannibalistic vampire motif does not appear to be a literary subject well suited to this High Classical period. Indeed, the image of the villainous vampire has been largely limited to trivial cultural works. However, this research proposes that Goethe's incorporation of "mentality" added a noble, spiritual dimension to his vampire, thus enabling the work to be classified as high literature (Schemme, 1986). From this perspective, it is important to analyze the ways in which the ghost motif is literalized in Goethe's poem. The literary construction resembles the description of an absolute love between vampire and human seen between characters Edward Cullen and Bella Swan in Stephenie Meyer's postmodern novels. Goethe's vampire bride has a form of humanity defined as her "spirit," while Meyer's Edward is similarly depicted as noble through an ethical persona.

Notably, Meyer's Twilight series has enjoyed massive success: enthusiastically embraced by not only youth, but also adult women (Paris, 2016). The novel emphasizes protagonist Edward's humanity through scenes involving team sports, and others where he is seen playing the piano beautifully for his love interest, Bella (and, later, for their human/vampire hybrid daughter, Renesmee). Traditionally, Western Christianity has viewed the vampire as evil. Accordingly, it is presented as such in Stoker's Dracula, killing innocent people in order to live. Thus, the vampire, a cruel murderer, is prototypically depicted as devoid of humanity. The binary construct of predator and prey is grounded upon the notion of cannibalism, which is actually present in many fairy tales (Fiedler, 1973). Historically, in folklore as well as fairy tales, most protagonists experience moral development as the story develops, culminating with marriage at the end, followed by the cliché: "and they all lived happily ever after". For instance, Cinderella of Grimm's Fairy Tales belongs to this prototype. She experiences moral development and marries the prince, allowing the reader to imagine a bright future for them (Fiedler, 1973). On the other hand, there is another type of story in which the oppositional concepts of predator and prey are expressed through the trope of cannibalism. In Grimm's Fairy Tales' Red Riding Hood, the wolf is a metaphor for a predator (Fiedler, 1973). The beast's wild and unconscious desire to eat the innocent girl presents a basic conception of the folklore, which also originates from mass culture. By considering the literary concept of cannibalism, the vampire subject can be analyzed in the tradition of folklore, because cannibalism is central to the notion of the vampirism.

Literary characteristics in the Twilight series and Goethe's Bride of Corinth should be discussed, especially in relation to the concept of cannibalism and absolute love. Edward of Meyer's Twilight is eternally 17 years old, and the consumption of blood maintains his life. This unconscious vampiric impulse is a foundational principle of the novel. The notion of the unconscious desire as a hidden crisis has fascinated human beings through the ages. Indeed, it is not new, being presented through the prototype of cannibalism in folklore or fairy tales. Though soulless, neither Edward nor the bride of Corinth can be reduced to mere cannibalistic characters, because they are spiritual and express emotions. Moreover, despite his vampire status, Edward learns to consume only the blood of animals, and never that of humans, overcoming the binary border between predator (life) and prey (death). This, along with his experience of emotional romance, is the means through which Twilight successfully depicts the high cultural "spirit" of the vampire first acknowledged by Goethe. Moreover, the film depiction of this phenomenon has ushered it into popular culture. In this way, the border between trivial and high literature is overcome through the subject of ethical vampires.

\section{Leslie Fiedler's concept of postmodernism and the image of cannibalism in fairy tales}

From the literature, it is evident that the motif of the undead has historical, religious, (anti-)gendering, literary, and artistic components, which have accordingly attracted the interest of scholars. In the $21^{\text {st }}$ century (during which the interest in vampires exploded), this subject is found not only in film but in the more popular medium of television, thereby garnering the attention of even the unlearned population accustomed to visual culture and media. One example of this is the wildly popular television series Buffy the Vampire Slayer. Notably, research has examined the gender-specific roles of vampires in Buffy (Recht, 2011). Clearly, the vampire subject traverses the boundaries of different mediums, from scholarly analysis to classical writings in the form of poetry, novels, and audio-visual media-becoming more culturally integrated over time. It is noteworthy that this constellation realizes Fiedler's literary concept of postmodernism. The vampire motif primarily crosses the border between high and popular culture.

In a 1990 interview (published a year later by the University of Toronto), Fiedler described his conceptualization of 
postmodern philosophy. Through modernism-defined as "the domination of [h]igh [c]ulture by the academy" (Fiedler, 1991, 331) — the masterworks of high literature were canonized through academic curricula. Subsequently, modern literature centralized the function of language itself, as a means of expression beyond the confines of convention (Andreotti, 2014). To this end, language became a material, such that the genre of postmodernism tends toward artistic approximation, meaning that modern literature could be interpreted only by those who could engage with artistic complexities (Andreotti, 2014). Since the literature and arts audience was determinate, the interpretative requirements became increasingly elitist — even authoritarian. Thus, the process of literary analysis was, for the most part, limited to academics. To make that fixed method more flexible, Fiedler put forth an effective method for bringing the literature into lectures. Furthermore, his suggestion is not only theoretical, but extends to praxis (how one may discuss the literature in the classroom). According to Fiedler, the high literary stuff were used in the classroom less in a classical canonized curriculum, but more in the context of popular culture so that the elitist materials became accessible not only to academics but also to young people who were familiar with new audiovisual media:

I have never, of course, despised the masterworks of recent High Literature, much less the classics canonized in the curriculum of classes in literature. Instead, I have tried to reread such authors as Joyce and Shakespeare in the context of popular culture, pointing out their indebtedness to the despised popular genres of their time. (...) To do so, I have had, on the one hand, to work out new classroom strategies - teaching books from both sides of the great divide in the same courses, rather than segregating them in ghettoized ones. (Fiedler, 1991, 331)

Fiedler cites Shakespeare as one of the typical authors of high literature whose works are taught at universities. In postmodern literature, Meyer's Twilight series reinterprets the motif of Shakespeare's tragedy in Romeo and Juliet (1597) by making a concept of absolute love between a spiritual vampire and a human being. Thus, the elements of elitist literature have connected with the elements of popular culture-a literary and educational strategy of postmodernism. In addition, Shakespeare's works, on the one hand, belonged to an elitist collection of world literature enjoyed through research and teaching by academics. Yet, on the other hand, Shakespeare's London Globe (a theater that originally opened in 1599) served to showcase plays for mass consumption. Curious audience members who wanted to observe while standing in the yard received access to the show for just a penny; these patrons became known as groundlings. Moreover, this low-cost option afforded access to Shakespeare's play to a mass audience, thereby shaping popular culture in his time. In this sense, constellation is pluralistic: involving both popular and elitist elements, effectively working "both sides of the great divide" (Fiedler, 1991, 331).

Notably, Shakespeare's most popular tragedy during his time, Romeo and Juliet, is intertextually referenced in Meyer's Twilight series. Moreover, Meyer's work reimagines the classic character of Romeo as a physically and spiritually idealized vampire in the form of the protagonist. An intellectual, Edward has perfectly memorized Shakespeare's story, commenting on the tragedy as he and Bella watch the film adaption on her birthday. Through this intertextual citation of a tragedy genre classic, the character's constellation becomes even more pronounced. Furthermore, the abnormal relationship between Edward, the vampire, and Bella, the human, is compared to the tragedy of Romeo and Juliet.

"You know, I’ve never had much patience with Romeo," he commented as the movie started.

"What's wrong with Romeo? I asked, a little offended. Romeo was one of my favorite fictional characters. Until

I'd met Edward, I'd sort of had a thing for him.

"Well, first of all, he's in love with this Rosaline—-don't you think it makes him seem a little fickle? And then, a few minutes after their wedding, he kills Juliet's cousin, That's not very brilliant. Mistake after mistake. Could he have destroyed his own happiness any more thoroughly?"

I sighed. "Do you want me to watch this alone?"

“No, I'll mostly be watching you, anyway.” His fingers traced patterns across the skin of my arm, raising goose bumps. (...)

The movie eventually captured my interest, thanks in large part to Edward whispering Romeo's lines in my ear-his irresistible, velvet voice made the actor's voice sound weak and coarse by comparison. (New Moon, 15-16)

This intertextual strategy casts a light of optimism on the love between Edward and Bella. Edward criticizes Romeo's behavior ("mistake after mistake"), demonstrating that he is conscious of the character's shortcomings. Thus, there is an implication that Edward will not make the same mistakes as Romeo, thereby allowing his romance 
with Bella to have a "happy ending”. Later, in New Moon, Edward is misled into believing that Bella has died. His resultant decision to commit suicide (before learning the information was untrue) has an analogical relation to the fates of Romeo and Juliet. Still, the story of Edward and Bella ultimately implies that they successfully overcome their challenges because of their enduring honesty. Meyer's Twilight successfully trumpets the motif of true romance using Shakespeare's lovers when Bella declares that "Romeo wouldn't change his mind. That's why people still remembered his name, always twined with hers: Romeo and Juliet. That's why it was a good story. 'Juliet gets dumped and ends up with Paris’ would have never been a hit” (New Moon, 326).

Since the 1990s, professors have increasingly incorporated unconventional materials into their lectures, including "soaps, sitcoms, cop shows, [and] comic books" (Fiedler, 1991, 333). This phenomenon exemplifies high and low culture analysis from a pop culture lens. Literature itself can bring these disparate artistic levels together in an entertaining way. Thus, many works of popular literature become international bestsellers. Interestingly, Fiedler's essay "Cross the border-Close the gap" notes that postmodernist work was first published by Playboy magazine in 1968. Some may have deemed it provocative to publish an academic essay in Playboy; however, it is a testament to the contradictory impulses (elitist and trivial) central to literary theory.

Notably, Fiedler's theory takes the first avenue: blurring the divide that has conventionally existed between high and low art. As society evolves, cultural values are changed through innovation (for instance, the introduction of new media such as computers, television, and film). Literature cannot continue as a medium in modern society if it ignores mass culture influences. As previously implied, a key characteristic of modern literature (pre-World War I until shortly after World War II) is its tendency to free language from its messaging function. The interpretation of modernism, therefore, became hermeneutic. Popular literature must be, in contrast, more "antiserious" and close "the gap between elite and mass culture" (Fiedler, 1972). In this sense, the latter strategy of abandoning plot, character, and setting is consistent with modernism. In Germany, Fiedler's philosophy has been embraced and enhanced by notable poet and storyteller, Rolf Dieter Brinkmann (1940-1975). The same can be said of Christian Kracht (1966-), the author of Faserland (1995), a novel heralded as representative of popular literature in the fatherland. Moreover, researchers tend to interpret the work according to its structural features, like its use of mostly colloquial language (Andreotti, 2014). By using high cultural media (novel), a first-person narrator in Faserland orally describes the plot which he experiences, through the use of casual language and colloquialisms, for instance, the repetitive mention of the popular dining room Fisch-Gosch in Sylt and the German popular beer brand Jever. The protagonist narrates his travel from northern German coast (Sylt) to the Swiss city of Zürich, where he hopes to visit the grave of Thomas Mann. However, he fails to find the tomb. The use of colloquialisms in the elitist literary genre is bridging the gap between popular and high culture, as suggested by Fiedler.

From this theoretical context, literary postmodernism is classified as a new mechanism of literary creation seen from the 1970s onward. In contrast, popular literature is much older. Folklore and fairy tales belong to this original genre, due to their long history of oral dissemination through the generations. Accordingly, they are a product of mass culture. Indeed, as early as the $17^{\text {th }}$ century, Charles Perrault had authored a book on the origins of storytelling, Stories or Tales from Past Times, with Morals (1697). Notably, there is also an oppositional contrast between respected academic writings and fairy tales, which are transmitted only in the oral tradition. For instance, among people in France and Germany, folklores went undocumented until authors collected them and printed them as a book. Fiedler explores the beginning of printed fairy tales as the first form of popular literature. Fiedler writes about this theme in the introduction of the anthology Beyond the Looking Glass (1973) in which Jonathan Cott brings together the most extraordinary examples of fantasy novels, stories, and poetry that have not been printed for many years. Fiedler examines how the literary genre of fairy tales, which are transmitted orally in mass culture, has been raised to a printed high literature by Charles Perrault:

The fairy tale entered the world of literature towards the end of the seventeenth century apologetically, proferring itself as one more pastoral entertainment for courtiers, and pretending to be the work not of the respected academician who sponsored it, but of his child and/or the Old Nurse of that child. Her voice had presumably droned on at the hearth for centuries, attended to but unrecorded, until in 1697, Charles Perrault committed it to print so that it could be heard in the salons of his own time, and, after the collapse of the ancient regime, could return via the bookstores to the nurseries of the post-Gutenberg world. (Fiedler, 1973, 12)

Perrault and Grimm collected fairy tales that were transmitted orally-and mostly by women, who were traditionally responsible for tending households and rearing children. Jeanette Hassenpflug is one of the women who shared what became known as Red Riding Hood with Grimm (Rölleke, 2019). This internationally beloved story 
describes the experience of an adolescent girl who ignores the advice of her mother and follows a wolf into the woods. Both she and her grandmother are eaten by the wolf, an act which embodies the latter's sexual impulse. The story is also understood as a metaphor for cannibalism. Perrault's Red Riding Hood died at the end of the story, swallowed by the wolf, while Grimm's version of the character was rescued when a hunter unexpectedly came to the grandmother's house. This story can also be analyzed from a psychological perspective, i.e., through the Oedipus complex (or Elektra complex for a girl). From this lens, the girl kills her grandmother by ignoring her advice not to enter the woods, all because she wants to accept the desire of the wolf (symbolizing a man, that is, her father; Bettelheim, 1976). Her bid for her father's affection fails in Red Riding Hood, and instead of engaging in incest, she is eaten by her father. This image of cannibalism is also connected to the Greek mythology of Cronus or Roman mythology of Saturn, and is depicted in Francisco Goya’s painting, Saturn Devouring His Son (1819-1823). Saturn consumes each of his five sons for fear of being killed by them in the future, as had been predicted. The depiction of parent/child cannibalism in fairy tales is particularly grotesque because it subverts the happy ending. Moreover, this destruction is enacted by the older, parental generation. This motivic structure of the past/the dead doing the eating and the future/the living being eaten is related to vampirism.

Some scholars have argued that it represents simply a vestigial memory of a time when human beings did in fact eat each other both ritually and in combat; or perhaps rather the vestiges of an attempt to exorcize that primordial hunger and the guilt it occasions — rather like the Christian Mass, which substitutes Bread and Wine for flesh and blood. Such historical explanations seem especially unsatisfactory, however, in a time like our own when cannibalism, especially in the form of vampirism, has become again a compulsive theme of popular literature, indeed a central feature of mass culture in general.

It is today possible, for instance, for a small child to buy in his local store a confection called "Vampire's Blood", with which, before swallowing it down, he can smear his own neck in a properly sanguinary way. (Fiedler, 1973, 14)

The fairy tale Red Riding Hood is, therefore, a significant example of vampirism as a theme of popular literature. Indeed, the literary genre of fairy tales can be interpreted as "the first form of popular literature" (Fiedler, 1973). Perrault's Stories or Tales from Past Times, with Morals as well as Grimm's Fairy Tales can also be interpreted as stories about "freaks," i.e., the dwarfs in Snow White, the witch in Hansel and Gretel, and the beast/wolf in Red Riding Hood. Those figures, deemed anomalies in the "real world," have normalcy in the fictional world of fairy tales, such that they are even presented as main characters. Often serving as protagonists, they are central to the stories themselves. One may even say that without the freaks, fairy tales become meaningless. Hence, the similarities in both literary genres-fairy tales and vampire literature-are based on the appearance of freaks that are, in both cases, transmitted orally, at first, into popular culture. The origin of these literary genres can be seen in mass culture and the authors have given an elitist literary form as written text. In fictional literature, freaks were almost created as fantasies. In nonfiction, they appear over the course of centuries through encyclopedias, cosmographies, medical treatises, books, etc. (Fiedler, 1978, 261). The vampires of popular literature can also be interpreted as freaks.

\section{The spiritual vampire in Goethe's Bride of Corinth}

The oldest vampire poem, Goethe's ballade Bride of Corinth, was composed in the Classical literary period. The emotional relationship between the female vampire and the pagan youth might be classified in the periodical category of "Sturm und Drang", a proto-Romantic literary movement spanning the late 1760s and early 1780s. This is because of the poem's focus on characters' passion and individual subjectivity. At first consideration, the subject of vampires does not seem to occur as a high classical motif because the undead subject is both soulless and ruthless: Finding eternal life vulgar and trivial, it seeks to victimize young people. The same can be said of Goya's painting Saturn Devouring His Son, in which vampirism is symbolically manifested in the frightening cannibalistic incident when the father (the old/past) eats his sons (the new/future). To reconstruct this vampire motif for the high literature of the Classical period, Goethe gave his main character, a female vampire, a "spirit." This divorces her from the image of a mere killer. In his artistic essay, Gedanken über den Gebrauch des Gemeinen und Niedrigen in der Kunst (1793), Goethe's contemporary, poet Friedrich Schiller, provides a definition of this spirit (Schemme, 1986).

As previously stated, Phlegon of Tralleis provided the original material Goethe used in his ballade centuries later. The $2^{\text {nd }}$ century source material, Das Buch der Wunder, was a collection of mystery stories concerning marginal figures (e.g., the undead, ghosts, 'freaks', hermaphrodites, transsexual persons, pregnant men, and giants). This lens was also taken up by Fiedler in the $20^{\text {th }}$ century in his monograph, Freaks-Myths and Images of the Secret Self 
(1978). The movie Freaks (1933), directed by Tod Browning, has similar thematic concerns, which it engages at the audio-visual level. Notably, this film was released just a year after his movie Dracula (1932). The word freak is the popular abbreviation for "freak of nature", a translation of the Latin lusus naturae. It is an umbrella term that refers to qualities, occurrences, and all manner of things deemed beyond the realm of everyday, "normal” human experiences. This includes oddities, malformations, abnormalities, anomalies, mutants, monsters and monstrosities, strange individuals, persons with special abilities, and phenomènes (Fiedler, 1978). Phlegon's anecdote about a young girl named Philinnion who returned from death undoubtedly influenced Goethe's poem. Notably, the girl is not a brutal vampire living on the blood of human beings, but merely a ghost.

A young man Machates comes in Tralles where his parent's friends live. It has not gone a half year yet since their daughter Philinnion passed away, but Machates did not know that. Every night, she comes to him, confesses her love, and they spend nights together. She disappears by day. However, servants noticed it and reported her mother Charito. As she is at the next night again with Machates, her parents come in and are delighted to see her. Philinnion tells her parents: "mother and father, how did you wrong to envy that I was together with the guest who has visited my father's house for three days. Then, I didn't do anything bad. Now, you have to be sad again because of your activity and I have to go back to the place where has been suggested. It was namely not without willingness of gods that I came here.” Soon after she tells these words to her parents, she falls down and dies. They burn her body outside the town, purify the temple and sacrifice it gods. After then, Machates loses his sanity and kills himself. (Phlegon, 19-27)

Philinnion's story demonstrates resurrection due to the hope of experiencing love. Because of absolute love, she returns from death and seeks her lover. Machates accepts her approach, and as a result a mutual love between ghost and human ensues. The literary structure indicates that the ghost is more passionate than the human; indeed, it is the ghost who passionately approaches Machates, suggesting that she is more active than the youth. Ultimately, however, Phlegon's anecdote is a tragedy, and both Philinnion and Machates pass away soon after her parents learn of the revival. Since she cannot permanently return to the world of the living, love motivates Machates to follow her into the realm of the dead.

Compared to Phlegon's Philinnion, Goethe's vampire bride is not active, because she knows that she must victimize the man she loves. By rewriting the character from ghost to vampire, Goethe emphasizes the definitive problem in romantic relationships underscored by cannibalism. It is evident in this case that the pagan youth will become a victim. Thus, the spiritually inclined vampire bride departs from the young man, although she wants to take his life. According to Fiedler, the description of the ethical vampire reverses the aggressive image of cannibalism in which the past (old/body/dead) destroys the future (young/spirit/alive). The dramatic dialog between the youth and the vampire bride is presented below as direct speech:

“(...) Ruhe nur so fort

Auf dem Lager dort,

Und ich gehe schnell, so wie ich kam.“

"Bleibe, schönes Mädchen!“ ruft der Knabe,

Rafft von seinem Lager sich geschwind:

“Hier ist Cere's, hier ist Bacchus' Gabe;

Und du bringst den Amor, liebes Kind!

Bist vor Schrecken blaß!

Liebe, komm und laß,

Laß uns sehn, wie froh die Götter sind.”

“Ferne bleib’, o Jüngling, bleibe stehen!

Ich gehöre nicht den Freuden an. (...)”

“(...) Liebchen, bleibe hier!

Feire gleich mit mir

Unerwartet unsern Hochzeitschmaus.” (Bride of Corinth, 269-270)
On thy soft couch now

Slumber calmly thou!

I'll return as swiftly as I came.

"Stay, thou fairest maiden!" cries the boy, Starting from his couch with eager haste:

“Here are Ceres', Bacchus' gifts of joy

Amor bringest thou, with beauty grac'd!

Thou art pale with fear!

Loved one let us here

Prove the raptures the Immortals taste.”

"Draw not nigh, O Youth! afar remain!

Rapture now can never smile on me (...)”

“(...) Sweetest, here then stay,

And without delay 
Clearly, they had no prior knowledge of each other, as the vampire bride meets the pagan youth the night he arrives in Corinth. Thus, they fall in love at first sight. Similarly, in Twilight, Edward and Bella soon know that they have a shared destiny - even without speaking much. Moreover, vampirism is a metaphor for sexuality in Goethe's Bride of Corinth and Meyer's Twilight, in which the lovers refrain from pre-marital sex. The human beings (Bella and the pagan youth) notably want to engage in intimacy, while the spiritual vampires refuse to do so until the wedding. The humans are aware that their loves are vampires from the realm of death. Therefore, the behavior of the ethical vampire according to two contrasting themes can be underlined in both literary works as "embracing" and "resisting." This exercise in juxtaposition will provide a foundation from which the paper can analyze the romantic relationship in Meyer's Twilight series. This will be followed by a discussion of the psychological similarities in the love between vampires and humans in both literary works.

The wedding reception in Goethe's ballade is framed by the tension between life and death. The vampire bride wants "one lock of [her lover's] hair", much like the Reaper takes one lock to bring humans to the realm of the dead. For his part, the young man wants to give her bread as a symbol of life as it is a conventional practice in Christian tradition, but she refuses to taste it. This scene symbolizes that the vampire bride cannot accept and enter the world of the living. The absolute wall between death and life is suggested in the wedding reception. Food is also a significant issue in Twilight at the beginning of Edward and Bella's courtship. They go to the restaurant La Bella Italia in Port Angeles; however, only Bella orders food, whereas Edward eats nothing (Twilight, 146-147). The food represents life, which only human beings can eat, therefore vampires, revived from death, refuse it. After the wedding reception in Bride of Corinth, the ethical vampire again rejects the earnest approach of the young man. However, as he begins to cry, she finally accepts his desire. According to Eckermann, the passionate dialog between vampire bride and the pagan youth is mostly inspired by Schiller. The ballade was printed in Schiller's Musen-Almanach für das Jahr 1798. Goethe carried the idea for Bride of Corinth for many years before he finally wrote it down. When he did, he reportedly felt as if he gave the words a body (Mayer, 1999). Upon its completion in June 1797, he was sad that he had to bid farewell, almost as if he was forever separated from beloved friends (Mayer, 1999). Moreover, he had been absorbed in the idea of mentality symbolized by the vampire. Goethe's poetological experience shows that the dialog between vampire and the youth relates not only to a written text as a material, but also to a lively body itself (Mayer, 1999).

In describing the couple's passion, the poem deals with religious differences. As previously stated, Corinth is a Christian town, and the bride's family is of that faith. Accordingly, the family buried the girl in a grave according to the principles of their religion, since cremation does not fall within the scope of traditional Christian burial rituals. Conversely, among pagans, funerals involving cremation are common. The vampire bride wants to be pagan like her lover because she would not need to return to the world of the living again and could finally attain spiritual peace. By the end of the poem, she has the ardent hope that she and her lover can visit the ancient gods and convince them of their love after being burned in the fire. Long before Goethe, Phlegon had already explored the symbolic meaning of cremation when his protagonist Philinnion died. The following is excerpted from the last stanza in which the vampire bride asks her mother to give the lovers eternal rest by burning:

Höre, Mutter, nun die letzte Bitte:

Einen Scheiterhaufen schichte du;

Öffne meine bange, kleine Hütte,

Bring' in Flammen Liebende zur Ruh'!

Wenn der Funke sprüht,

Wenn die Asche glüht,

Eilen wir den alten Göttern zu. (Bride of Corinth, 273)

Mother, to this final prayer give ear!

Let a funeral pile be straightway dress'd;

Open then my cell so sad and drear.

That the flames may give the lovers rest!

When ascends the fire

From the glowing pyre,

To the gods of old we'll hasten, blest.

Bride of Corinth can be interpreted as a tragedy. Both the vampire bride and the pagan youth are finally connected in love; however, the border between life and death is so definitive that the vampire cannot live with him forever. From the moment they loved each other, it was determined that he had to follow her into the realm of death. Accordingly, the bride tells her Christian mother that they want cremation instead of burial. Most importantly, it is the former process that would enable them to visit the ancient gods together and avoid returning to the world of the living as vampires who kill human beings. The continuity of the body is at last halted and the mentality of the vampire and human are eternally connected in love. 


\section{Meyer's Twilight series as postmodern literature: between cannibalism and happy ending}

The love between vampires and humans is an essential theme in both The Bride of Corinth and Twilight. These vampires have their mentality manifested by their behavior, which oscillates between resisting and embracing love. Instead of the trope of vampire as a villain, Edward appears both physically and spiritually perfect. As he hunts, run swiftly, springs, climbs, and throws, his physical prowess is emphasized-and framed as a testament to his masculinity. His more spiritual side is demonstrated through his affection for music, his skill on the piano, and the restraint with which he handles his distinctly carnal desire for blood in order to protect Bella. Classic tropes concerning the supposed weaknesses of the vampire, like sunshine, garlic, mirrors, or crucifixes, are symbolically overcome in Chapter 13 "Confessions", when Edward's skin sparkles in the sun "like thousands of tiny diamonds" (Twilight, 228). Also, he is forever 17 years old, an adolescent. Contrariwise, the human Bella ages.

In his elegant restraint, the idealized Edward mirrors a characteristic seen in Goethe's Bride of Corinth. After Edward and Bella are struck by love at first sight, he imposes a separation between them in New Moon. This is prompted by the cannibalistic desire inherent to vampires and his loving desire to protect Bella's life. In this way, he subdues his own emotions to do what is best for his love interest, as implied by the statement that he left "her for her" (New Moon, 453). Thus, Edward's decision to leave her is a selfless act. Similarly, Schiller presents the notion of altruism as an act of "human nobility" (Schiller, 1973). In Chapter 23, "The Truth", the couple has reunited, and Edward explains why he had to leave Bella:

I only left you in the first place because I wanted you to have a chance at a normal, happy, human life. I could see what I was doing to you - keeping you constantly on the edge of danger, taking you away from the world you belonged in, risking your life every moment I was with you. So I had to try. I had to do something, and it seemed like leaving was the only way. If I hadn't thought you would be better off, I could have never made myself leave. I'm much too selfish. Only you could be more important than what I wanted...what I needed. (New Moon, 452)

The passionate dialog continues until they understand how to rebuild their relationship. One solution Bella identifies and strongly desires is to become a vampire. Much as Goethe's vampire bride wants to wait until the wedding ceremony to concede to her beloved's requests for sexual intimacy, Edward also wants to wait until the wedding with Bella before he changes Bella into the vampire. The ritual celebration crucial to the realization of their marriage vow "as long as we both shall live", and becomes a triumph for both (Breaking Dawn, 45). Although Edward's heart stopped nearly 90 years before, the existence of immortal couples is described as far happier than that of a human being facing death. From this perspective, Bella argues against Edward's restraint, because she is ready to leave normal human life behind. Bella is certainly more eager for this than Edward, mirroring the relationship between the pagan youth and the vampire bride in that respect. As the narrator throughout the Twilight Saga, it is Bella's perspective of the relationship that becomes increasingly dominant during the story. In the following quote, Bella and Edward discuss a potential time frame for him to transform her.

He smiled faintly, and then pursed his lips. "Five years?” My face twisted into an expression somewhere between chagrin and horror. "You said anything," he reminded me. "Yes, but...you'll use the time to find a way out of it. I have to strike while the iron is hot. Besides, it's just too dangerous to be human-for me, at least. So, anything but that.” He frowned. "Three years?” "No!” “Isn’t it worth anything to you at all?” I thought about how much I wanted this. Better to keep a poker face, I decided, and not let him know how very much that was. It would give me more leverage. "Six months?” He rolled his eyes. "Not good enough.” “One year, then,” I said. “That's my limit.” "At least give me two." "No way. Nineteen I'll do. But I'm not going anywhere near twenty. If you're staying in your teens forever, then so am I.” (New Moon, 476-477)

This exchange again demonstrates Edward's concern with what is best for Bella. Changing her into a vampire is a straightforward process; however, he appreciates the value of natural human life. This characterization of a vampire is far from the image of the "vulgar [creature] who is thinking only [of] his profit" (Schiller, 1973) and victimizes human beings to drink their blood. The superior morality of Edward is even reinforced by descriptions of his angelic appearance. He has humanity and behaves with such elegance toward his human love that the trivial subject of the vampire is elevated to a high literary material.

The idealized vampire Edward is ultimately successful in his love for, and relationship with, Bella. The male werewolf character of Jacob Black, however, is frequently presented as a threat to the union and as both Edward's nemesis and opposite. Jacob attempts to repress and police his emotions so that he is not able to express his feelings of love for Bella. Significantly, with a werewolf, the possibility of a violent outburst is ever present, as is often the case 
in $21^{\text {st }}$ century representations of masculinity in popular culture (Evans, 2019). In New Moon, Jacob is framed as the embodiment of hegemonic masculinity through his transformative body. Thus, Edward's capacity for reason (mentality) and his humanity are accentuated through this juxtaposition. Interestingly, both the vampire and the werewolf are freaks and fear-inspiring monsters. However, Edward's psycho-emotional traits allow him to expresses his feeling to, and for, Bella in a far more sensible, refined way. Edward appears to have far more self-control and emotional maturity than Jacob in most instances. In New Moon, after Edward leaves Bella for her safety, Jacob asks Bella several times if she wants to become his girlfriend. She refuses due to her devotion to Edward and the Cullen family. Jacob turns into a werewolf and fumes with anger and noticed that he is an opposite of the vampires. He turns into a wolf when he becomes angry, and he is unable to control his emotions in most cases. In these situations, Bella hears Edward's voice in her head saying, "Give [Jacob] a chance to calm down” (New Moon, 237). This shows that Edward behaves noble not only for himself, but is also able to read a person's mind and understands the right way to act. It can be seen as an indication of his noble character and strength of mentality.

Per classic vampire literature, the vampire naturally has a cannibalistic desire. However, when he spends time with Bella, her fear of becoming a victim rapidly disappears. The reason for this is that he demonstrates noble character/humanity. In addition, Edward has a sense of humor, which also has the effect of humanizing him. Indeed, laughter is a distinctly human capability (Bergson, 1900). From this perspective, Edward's behavior tends more toward the psycho-emotional aspects of humanity than hegemonic masculinity, as expressed as the aggressive anger of Jacob, the transformative werewolf. In the following quote, the couple discusses the issue of cannibalism as a feature of the vampire's nature. Edward explains his hunting habits in a witty way despite the apparent seriousness of the situation:

"Tell me why you hunt animals instead of people," I suggested, my voice still tinged with desperation. I realized my eyes were wet, and I fought against the grief that was trying to overpower me. "I don't want to be a monster."

His voice was very low. “But animals aren’t enough?” He paused. “I can’t be sure, of course, but I'd compare it to living on tofu and soy milk; we call ourselves vegetarians, our little inside joke. It doesn't completely satiate the hunger —or rather thirst. But it keeps us strong enough to resist. Most of the time”. His tone turned ominous. "Sometimes it’s more difficult than others." (Twilight, 163-164)

The conversation about cannibalism addresses the couple's most serious problem. Beyond being monumental, the issue is ever-present and Bella is in a perpetual state of possible victimhood because of it. This dangerous predicament in which the past (the undead) eats/destroys the future (human beings) also appears in Grimm's Red Riding Hood. However, in the following exchange from Twilight, it is converted into a point of humor through metaphor. Edward explains to Bella the reason why the vampire was born:

"So where did it all start? I mean, Carlisle changed you, and then someone must have changed him, and so on..."

"Well, where did you come from? Evolution? Creation? Couldn't we have evolved in the same way as other species, predator and prey? Or, if you don't believe that all this world could have just happened on its own, which is hard for me to accept myself, is it so hard to believe that the same force that created the delicate angelfish with the shark, the baby seal and the killer whale, could create both our kinds together?" "Let me get this straight—I'm the baby seal, right?” "Right.” He laughed, and something touched my hair—his lips? (Twilight, 269)

Humor is rarely achieved through predictability. Often, it is when something happens unexpectedly or is performed in an unintended way that it becomes comical. Moreover, if a matter concerning personal weakness or social defects is not taken seriously, laughter will ensue (Bergson, 1900). In the above dialog, cannibalism is framed as a natural desire among vampires. Edward expresses the serious situation of bloodlust in vampirism, an unconscious, wild impulse, with unexpected metaphors, i.e., the delicate angelfish versus the shark or the baby seal versus the killer whale. Thus, this grave topic is mitigated through witty words. The romantic, charm-filled relationship between Edward and Bella proceeds with optimism and is expected to culminate in the proverbial happy ending, while the grotesque issue of cannibalism is relegated to the background through comical expression.

The cannibalistic motif is primarily seen in the literary genre of fairy tales. As already discussed, Fiedler suggests that Red Riding Hood can be interpreted as a prototype of the cannibalistic subject. The title character's grandmother — who lived alone, deep in the forest—had fallen sick. Red Riding Hood goes to see her and bring her wine and bread. However, the secluded woods are also the realm of the wolf, and where cannibalism takes place. This aspect of the fairy tale is mirrored by the setting of the Twilight Saga: a small town called Forks, which is densely 
surrounded by forests. Adding to the isolation is the near-constant cloud coverage and rain. Forks is said to experience more downpour than any other place in the United States. The woods framing the town symbolize lawlessness: a space where uncontrollable, unconscious impulses can arise. Thus, the cannibalistic threat of vampirism is reinforced through the novel's location.

As previously stated, the vampire is typically presented as villainous, more specifically, as a form or manifestation of evil. In a strictly corporal sense, they have a body that has been revived, but not the permanent soul that endures even after death. The concept of the immortal soul is a foundational principle of Christianity. The undead's soulless body is unacceptable or alien to this core belief system and conflated with paganism. This religious concept is also thematized in Goethe's Bride of Corinth, in which the pagan youth visits the Corinth home where the vampire bride has returned after death. By the end of Goethe's ballade, the couple wants to jump into a fire (cremation) to make certain they will not have to return to the world of the living as members of the undead. In Twilight, religious juxtaposition comes to the fore in the form of Carlisle, who represents the new image of the vampire put forth by the saga. Carlisle is the patriarch of the Cullen family, and 362 years old. In the 1600s, when he was still human, he reluctantly worked as a vampire hunter-forced to do so by his staunchly Anglican father who saw these paranormal creatures as abominations. Unfortunately, Carlisle is eventually bitten and turned by one of the vampires he uncovers. Still, he does not want to commit the same cannibalistic evils and resolves to control his cannibalistic desire. After practicing for 200 years, Carlisle has the extraordinary restraint required to work as a surgeon. He and his entire family are, as Edward jokes, "vegetarians" (Twilight, 164), since they do not hunt human beings anymore. This is, in effect, a family tradition made possible by Carlisle's efforts beginning all those years ago. Moreover, the impulses that underscore Edward's remarkable humanity, which fascinates Bella, can be traced to his father Carlisle's dedication to saving lives. Meyer successfully subverted the villainy of the vampire by fundamentally changing its cannibalistic lifestyle. Instead of harming humans, they try to help them, e.g., Carlisle in his medical profession. Goethe, however, uses tragedy to distance his work from the classical image of the vampire as a demonic killer: employing a pagan aesthetic as the lovers' opt for a fiery end (cremation).

Returning to Meyer's series, Edward's status as a spiritual, ethical vampire clearly captures Bella's sympathy and admiration. Moreover, this image has sparked the same reaction in an intergenerational, largely female fandom that pervades the globe. The enormous number of fan-written stories called "fan fiction" or "fanfic" were inspired by the novels, while fan sites such as TwilightLexicon.com allow online discussion about the novels (Day, 2014). Bella is, of course, an adolescent female and the novel focuses primarily on her emotional life, particularly her romance with Edward. Both factors may explain why the series has seen such success among women and girls. Accordingly, the two most popular websites for fans the series are TwilightTEENS and TwilightMOMS (Paris, 2016). Research shows that these intergenerational female fans can fashion their own versions of their favorite characters, create and share content (e.g., fantasies) with other women, encourage other users to find sources of sexual inspiration, and transfer that emotional and sexual intensity over into their own relationships (Paris, 2016). Edward's postmodern vampire image (a function of his humanity) has therefore influenced the contemporary gender roles of young and adult women. Conversely, the image of violent, transformative werewolf Jacob has reinforced dominant gender expectations concerning masculinity, e.g., concealing one’s emotions and weaknesses (Evans, 2019).

As previously stated, Bella and Edward's romance has a happy ending, which contrasts with the endings of Shakespeare's Romeo and Juliet and Goethe's Bride of Corinth. This may be because the cannibalistic model of murderer and victim is made salient in the latter work, such that the border between vampire and human is impossible to overcome. This image of tragic love, that is, the existence of an absolute, insurmountable divide, has dramatically changed in postmodern, popular literature, as evidenced by the Twilight Saga.

After the marriage ceremony in Breaking Dawn, Bella is changed to a vampire. Vampires are said to be at their strongest in the first year following their transformation; thus, she is more physically and mentally proficient than the male characters. Moreover, she has a special ability to protect herself from danger, and is described as a "shield." This ability also allows her to protect others by focusing all her internal energy on doing so, effectively "shield[ing] someone besides [her]self” (Breaking Dawn, 555). In her human years, Bella was always protected by male characters, such as Edward, Jacob, and even her father Charlie, during crises. Thus, she symbolizes not only beauty, but also a weakness, being a young girl perpetually in danger of a cannibalistic attack. She becomes empowered once she becomes a vampire wife, taking an active role in fighting for herself, her husband Edward, and, later, their daughter, Renesmee. Gone are the days of passivity that characterized much of her human life. This brilliant metamorphosis of internal character was notably made possible by the physical metamorphosis, allowing her to occupy a more involved 
role in the life in the vampire family. At the end of the novel, the fight against the Volturi presents an opportunity for Bella to uses her outstanding talent to build a "shield" to protect her encampment. In the self-titled final section (part three) of Breaking Dawn, Bella is shown to be more physically dominant/powerful than male vampires during a fight. Told from her perspective, part three, and the story, ends with Bella as not only narrator, but also heroine.

I threw my shield with all the force in my mind, flung it across the impossible expanse of the field—-ten times my best distance-like a javelin. My breath rushed out in a huff with exertion.

The shield blew out from me in a bubble of sheer energy, a mushroom cloud of liquid steel. It pulsed like living things - I could feel it, from the apex to the edges.

There was no recoil to the elastic fabric now; in that instant of raw force, I saw that the backlash I'd felt before was of my own making - I had been clinging to that invisible part of me in self-defense, subconsciously unwilling to let it go. Now I set it free, and my shield exploded a good fifty yards out from me effortlessly, taking only a fraction of my concentration. I could feel it flex like just another muscle, obedient to my will. I pushed it, shaped it into a long, pointed oval. Everything underneath the flexible iron shield was suddenly a part of me-I could feel the life force of everything it covered like points of bright heat, dazzling sparks of light surrounding me. (Breaking Dawn, 641-642)

The struggle against the Volturi finally ends, as they recognize that Renesmee's hybrid status poses no threat to their kind. Bella's strength in producing the protective shield is acknowledged by Edward, who "analyzing every shift of intention and control that had happened in the meadow today, declar[es] that it was [her] shield that had made the Volturi run away with their tails between their legs” (Breaking Dawn, 693). From the perspective of gender, Bella's physical strength is emphasized in Breaking Dawn, while the male characters (mainly Edward and Jacob) are presented as physically dominant in the first three novels (Twilight, New Moon, and Eclipse) because of their supernatural abilities.

In contrast to Goethe's tragic ballade, Bride of Corinth, Meyer's Twilight Saga has a happy ending. Indeed, the last chapter is entitled "The Happily Ever After"-an obvious nod to the ending of one prototypical fairy tale: the story of Cinderella. After overcoming all her challenges, Cinderella married the prince and lived happily ever after, while the other prototype, Red Riding Hood, is eaten by a wolf deep in the forest (Fiedler, 1973). Of course, this reinforces Fiedler's theory concerning two main prototypes of fairy tales: cannibalism and the happy ending (Fiedler, 1973). Notably, in Meyer's Twilight Saga, Bella develops both physically and mentally, especially through her metamorphosis from a human to a vampire. Her happy ending is literally eternal due to her and Edward's immortal state and their peaceful victory over the Volturi. Beyond this, her status as a shield has not only allowed Bella to find her strength, it provides the peace of knowing she can protect her family against any dangers to come. As a subject, she undergoes development throughout the saga of love with her idealized vampire. In the end, they continue "blissfully into this small but perfect piece of [their] forever" (Breaking Dawn, 699). As popular literature, the Twilight Saga paradoxically includes two different essences of fairy tales: cannibalism as an existential crisis of predator versus prey, and the happy ending in form of the enduring love between Edward and Bella.

\section{Conclusion}

The emotional love between spiritual vampires and human beings was thematized as an essential motif in Goethe's The Bride of Corinth (1797) as well as Meyer's Twilight Saga (2005-2010). Traditionally, vampires have been presented and perceived as soulless villains due to their cannibalistic nature. The discourse of vampires as violent killers does not seem suited to the High Classical literary period at the end of the $18^{\text {th }}$ century. However, Goethe's poem presents the image of a spiritual vampire bride by adapting a ghost story from the ancient Greek author Phlegon of Tralleis. Thus, Goethe's vampire motif is enhanced through the vampire's mentality (or sense of ethics), and the ballade describes the vampire's humanity in an esthetic way (Schemme, 1986). The cannibalistic image of the vampire is overcome through the absolute love between the Christian vampire bride in Corinth and the pagan youth from Athens. Similarly, the subject of the ethical, spiritual vampire crosses the border of trivial and high literature through the idealized vampire Edward in Meyer's popular series. Originally intended for a teen readership, Twilight found a significant fanbase in adult women, which propelled it to international bestseller status (Paris, 2016). In this way, the tale of the spiritual vampire and his love has made an intergenerational impact on global popular culture.

Instead of violence, Edward demonstrates an elegant restraint for the sake of protecting Bella, a theme which also appears in Goethe's ballade. Both works present a literary structure in which a human being (Bella/the pagan boy) is 
actively approaching a vampire (Edward/bride of Corinth) to escalate their love/relationship. Conversely, the vampires are shown to have noble intentions wish to postpone sexual intimacy (and, in Bella and Edward's case, physical transformation) until marriage. Through a comparative analysis, this paper explores the literary motif of vampirism in Goethe and Meyer's texts. Moreover, it explores the ways in which these works overcome the divide between triviality and elitism using the central theme of vampires and human beings. Ultimately, the love in Goethe's ballade ends tragically, as the youth commits suicide through cremation. Edward and Bella, however, enter a world of new experiences after their union and her transformation into a vampire. As her characters achieve their "Happily Ever After" (Breaking Dawn, 688), Meyer's Twilight achieves the high classical literature motif of true love, much like that of Shakespeare's Romeo and Juliet (1597) and the young lovers in Goethe's poem. This paper considers Leslie Fiedler's theoretical concepts of literary postmodernism and fairy tales, namely the opposed category of cannibalism and the happy ending, as a basis for literary analysis.

\section{References}

Andreotti, Mario. (2014). Serie: “Cross the Border-Close the Gap”. In Sprachspiegel 70.4 (pp. 119-121). Zürich: SVDS.

Bergson, Henri. (2014). Laughter: An Essay on the Meaning of the Comic (1900). Eastford: Martino Fine Books.

Bettelheim, Bruno. (1976). The Uses of Enchantment. Meaning and Importance of Fairy Tales. New York: Alfred A. Knopf.

Browning, Tod. (1931). Dracula. USA: 75 min.

Capozzi, Rocco and Fiedler, Leslie. (1991). An Interview with Leslie A. Fiedler: Let’s Revisit Postmodernism. In University of Toronto Quarterly 60.3 (pp. 331-336). Toronto: University of Toronto Press.

Condon, Bill. (2011). Breaking Dawn and Twilight Saga. Part 1. USA: 117 min.

Condon, Bill. (2012). Breaking Dawn and Twilight Saga. Part 2. USA: 116 min.

Cott, Jonathan and Fiedler, Leslie (Eds.) (1973). Beyond the Looking Glass, Extraordinary Works of Fairy Tale \& Fantasy. New York: Stonehill Publishing Company.

Day, Sara K. (2014). Pure Passion: The Twilight Saga, “Abstinence Porn”, and Adolescent Women’s Fan Fiction. In Children’s Literature Association Quarterly (pp. 28-48). Baltimore: Johns Hopkins University Press.

Dreyer, C. T. (1932). Vampyr. Germany \& France: 71 min.

Endes, Johannes. (2020). Vampires and the Orient in Goethe’s “Die Braut von Corinth”. In The German Quarterly 93.2 (pp. 204-220). Hoboken: John Wiley \& Sons.

Evans, Tania. (2019). Full Moon Masculinities: Masculine Werewolves, Emotional Repression, and Violence in Young Adult Paranormal Romance Fiction. In Gothic Studies 21.1 (pp. 28-39). Edinburgh: Edinburgh University Press.

Fiedler, Leslie. (1972). Cross the Border-Close the Gap (pp. 61-85). New York: Stein \& Day.

Fiedler, Leslie. (1978). Freaks. Myths and Images of the Secret Self. New York: Doubleday.

Fisher, Terence. (1958). Horror of Dracula. UK: 81 min.

Göbel, Jelka. (2012). Neues Jahrtausend, Neuer Vampirfilm? Kontinuität und Wandel eines Genres. Marburg: Tectum.

Goethe, Johann Wolfgang von (2000a). Der Gott und Die Bajadere. Indische Legende (1797). In E. Trunz (Eds.), Johann Wolfgang von Goethe Werke. Hamburger Ausgabe, Bd. 1. Gedichte und Epien (pp. 273-276). Munich: Deutscher Taschenbuch Verlag.

Goethe, Johann Wolfgang von (2000b). Die Braut von Korinth (1797) In E. Trunz (Eds.), Johann Wolfgang von Goethe Werke. Hamburger Ausgabe Bd. 1. Gedichte und Epien (pp. 268-273). Munich: Deutscher Taschenbuch Verlag.

Goethe, Johann Wolfgang von (2000c). Paria (1824). In E. Trunz (Eds.), Johann Wolfgang von Goethe Werke. Hamburger Ausgabe Bd. 1. Gedichte und Epien (pp. 361-367). Munich: Deutscher Taschenbuch Verlag.

Hardwicke, Cathrine. (2008). Twilight. USA: 117 min.

Kuzui, Fran Rubel. (1992). Buffy the Vampire Slayer. USA: 86 min.

Mayer, Mathias. (1999). Goethes Vampirische Poetik. Zwei Thesen zur Braut von Corinth. In W. Barner, C. Lubkoll, E. Osterkamp, U. Ott (Eds.). Jahrbuch der Deutschen Schillergesellschaft (pp. 148-158). Stuttgart: Alfred Kröner Verlag. 
Meyer, Stephenie. (2005). Twilight. London: Atom.

Meyer, Stephenie. (2006). New Moon. London: Atom.

Meyer, Stephenie. (2007). Eclipse. London: Atom.

Meyer, Stephenie. (2008). Breaking Dawn. London: Atom.

Meyer, Stephenie. (2010). Short Second Life of Bree Tanner. London: Atom.

Murnau, F. W. (1922). Nosferatu. Germany: 64 min.

Paris, Leslie. (2016). Fifty Shades of Fandom: The Intergenerational Permeability of Twilight Fan Culture. In Feminist Media Studies 16.4 (pp. 678-692). London: Routledge.

Phlegon, von Tralleis and Brodersen, Kai (Eds.) (2002). Das Buch der Wunder, und Zeugnisse seiner Wirkungsgeschichte (pp. 19-46). Darmstadt: Wissenschaftliche Buchgesellschaft.

Recht, Marcus. (2011). Der sympatische Vampir. Visualisierungen von Männlichkeiten in der TV-Serie Buffy. Frankfurt/New York: Campus Verlag.

Rölleke, Heinz and Albert, Schindehütte (Eds.) (2019). Es war einmal... die wahren Märchen der Brüder Grimm und wer sie ihnen erzählte (pp. 284-288). Berlin: Die Andere Bibliothek.

Schemme, Wolfgang. (1986). Goethe: Die Braut von Korinth. Von der literarischen Dignität des Vampirs. In T. Lewandowski (Eds.) Wirkendes Wort. Deutsche Sprache in Forschung und Lehre 36 (pp. 335-346). Düsseldorf: Schwann-Bagel.

Schiller, Friedrich. (1980). Gedanken über den Gebrauch des Gemeinen und Niedrigen in der Kunst. (1793). In L. Bellermann (Eds.) Schillers Werke 7 (pp. 223-230). Leipzig: Bibliographisches Institut.

Shakespeare, William. (1980). Romeo and Juliet (1597). In H. F. Brooks, H. Jenkins, and B. Morris (Eds.). Arden Shakespeare -. Romeo and Juliet (pp. 79-235). London/New York: Methuen.

Slade, David. (2010). Eclipse. USA: 119 min.

Trunz, Erich. (2000). Johann Wolfgang von Goethe Werke. Hamburger Ausgabe, Bd. 1. Gedichte und Epien (pp. 662-666, 724-726). Munich: Deutscher Taschenbuch Verlag.

Weitz, Chris. (2009). New Moon. USA: 130 min. 